\title{
USE OF CHLORITES FOR TREATING RAW SUGARS
}

\author{
By Horace S. Isbell
}

\section{ABSTRACT}

The use of sodium and calcium chlorites for the bleaching of raw-sugar crystals and sugar sirups was investigated and a method for treating raw sugar was devised. Chlorites in neutral and slightly acid solutions exert a slow bleaching action on the colored impurities in raw sugar. In addition to the bleaching action, chlorites have marked bactericidal properties, so that treatment of raw sugars and sugar solutions with chlorites inhibits bacterial action. Inasmuch as pure sucrose is not altered by contact with chlorites at room temperature for long periods, the chlorite can remain in contact with the sugar crystals in storage and reduce the loss of sugar ordinarily caused by bacterial action.

\section{CONTENTS}

I. Introduction

II. Treatment of crystalline raw sugar in storage $\ldots \ldots \ldots \ldots 2$

III. Experiments with sugar solutions

\section{INTRODUCTION}

Heretofore various chemicals-such as chlorine, sodium hypochlorite, chlorine dioxide, peroxides, and other rengents-have been used for bleaching sugars and sugar solutions, but these have not been wholly satisfactory. Recently the Mathieson Alkali Works has made commercially available a compound, sodium chlorite, which appears to have valuable properties as a bleaching agent. ${ }^{1}$ Inasmuch as the literature did not reveal the chemical behavior of the simple carbohydrates with chlorites, the author, in collaboration with Allene Jeanes, undertook an investigation of the reactions of chlorites upon such diverse carbohydrate materials as pure sugars, sugar alcohols, aldonic acids, and glycosides. ${ }^{2}$ In the present paper, experiments are reported to show the application of the new reagent in the treatment of raw sugars and sugar sirups.

The investigation has revealed that pure sucrose is not altered by contact with chlorites at room temperature for a period of over 100 days, and that in acid solution, chlorites have a marked bleaching action on the colored impurities in raw sugar. In neutral solution the bleaching action was found to be very slow and to require several days at room temperature. The bleaching action is rapid in acid solution, but since sucrose is hydrolyzed readily by acids at high temperatures, these conditions cannot be employed in a technological process. In

\footnotetext{
1 M. C. Taylor, J. F. White, G. P. Vincent, and G. L. Cunningham, Ind. Eng. Chem. 32, 899 (1940). M. C. Taylor, J. F. White, and G. P. Vincent, Techn. Assn. Papers, Series XXIII, No. 1 (1940).

A. Jeanes and H. S. Isbell, J. Research NBS 27, 125 (1941) RP1408.
} 
spite of these inauspicious circumstances, a practical process for treating raw sugar was devised. In this process the slowness of the bleaching action is not objectionable because the bleaching agent is allowed to remain in contact with the raw sugar while it is in storage. In the early stages of this investigation it was noted that molds develop in sugar solutions which have not been bleached or which have been bleached with hypochlorites, but that molds do not ordinarily develop in solutions bleached with chlorites. The marked difference in the behavior of the solutions treated with hypochlorite and those treated with chlorite probably arises from the difference in the rates of reaction for the hypochlorite and chlorite. The hypochlorite reacts quickly with the organic material and is reduced to chloride, which has little or no bactericidal effect. Chlorites, however, react slowly and remain in solution for a long time and thus exert a prolonged bactericidal and fungicidal action. Because of this characteristic the addition of a chlorite to a raw sugar prevents the growth of bacteria and molds and at the same time results in a slow bleaching action.

\section{TREATMENT OF CRYSTALLINE RAW SUGAR IN STORAGE}

Ordinarily considerable time elapses between the production of raw sugar and its use at the refinery. During this period there is some loss of sucrose by the action of bacteria and molds, and consequently the addition of a bactericidal agent is advantageous. Spraying the raw-sugar crystals with a solution of sodium or calcium chlorite would introduce the bleaching agent into the film of molasses which coats the sugar crystals, and reaction would take place slowly during the storage period. Since the bacterial action takes place in the molasses film, the presence of the chlorite at this point would seem to be particularly opportune. In the refining process the raw sugar, which has been in storage for varying lengths of time, is affined (that is, mixed with water or sirup to make a magma and centrifuged). This removes the bulk of the impurities and a large portion of the color which is in the film of molasses coating the crystals. In the process contemplated the excess chlorite and buffer would be removed with the affination sirup and subsequently processed to yield light-colored sirups.

The experiments outlined in table 1 show the behavior of raw sugar when treated with chlorites, both in the absence and in the presence of buffering agents. In each experiment the raw sugar was thoroughly mixed with the chlorite and the other reagents in the proportions given. The mixture of raw sugar and reagents was transferred to a glassstoppered bottle and was allowed to stand at room temperature in a dark place. At the designated times, samples of the sugar were taken and the intensity of the color (specific absorptive index) was determined with the simplified apparatus and by the method described by Brewster. ${ }^{3}$ For comparison, each "absorptive index" was divided by the "absorptive index" of a sample of the sugar which had been mixed with a like quantity of water and allowed to stand for the same time. The values thus obtained are given in the column designated "relative absorptive index." The acidity of the crystalline raw sugar could not

8 J. F. Brewster, J. Research NBS 16, 349 (1936) RP878. 
be determined directly, and consequently measurements were made with solutions prepared by dissolving 1 part of the sugar in 3 parts of water. The color of the raw sugar, after treatment with either sodium or calcium chlorite in acid solution, decreased perceptibly in the course of several hours, reaching a minimum in most cases in the course of several days. The decrease in color depends in large measure on the amount of chlorite added. In the experiments in which considerable chlorite was added, the bleaching action was accompanied by the evolution of chlorine dioxide; but when small quantities of chlorite were used, the presence of chlorine dioxide was not apparent.

TABLE 1.-Treatment of crystalline raw sugar

\begin{tabular}{|c|c|c|c|c|c|c|c|c|c|c|}
\hline \multirow[b]{3}{*}{$\begin{array}{l}\text { Ex- } \\
\text { peri- } \\
\text { ment }\end{array}$} & \multirow[b]{3}{*}{$\begin{array}{c}100 \mathrm{~g} \text { of raw sugar treated with the re- } \\
\text { agents listed below }\end{array}$} & \multicolumn{9}{|c|}{$\begin{array}{c}\text { Results after the sugar mixture had stood at room } \\
\text { temperature for- }\end{array}$} \\
\hline & & \multicolumn{3}{|c|}{1 day } & \multicolumn{3}{|c|}{7 days } & \multicolumn{3}{|c|}{55 days } \\
\hline & & 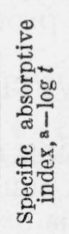 & 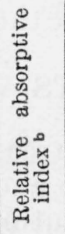 & $\begin{array}{l}\text { 四 } \\
0 \\
0 \\
\stackrel{0}{0} \\
\stackrel{0}{0}\end{array}$ & 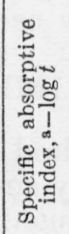 & 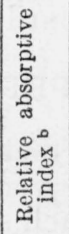 & 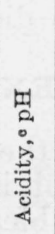 & 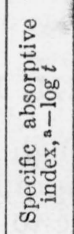 & 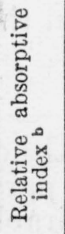 & 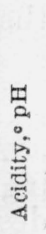 \\
\hline $\begin{array}{ll}1 \\
2 \\
3 \\
4 \\
5\end{array}$ & $\begin{array}{l}2 \mathrm{ml} \text { of } \mathrm{H}_{2} \mathrm{O} \\
2 \mathrm{ml} \text { of } 25 \% \mathrm{NaClO} \mathrm{NaClO}_{2}+1 \mathrm{ml} \text { of } \mathrm{H}_{2} \mathrm{O} \\
1 \mathrm{ml} \text { of } 25 \% \mathrm{NaCl}_{2} \mathrm{ml} \text { of } 12.5 \% \mathrm{Ca}\left(\mathrm{ClO}_{2}\right)_{2} \\
1 \mathrm{ml} \text { of } 25 \% \mathrm{NaClO}_{2}, 1 \mathrm{ml} \text { of } \mathrm{H}_{2} \mathrm{O}+2 \mathrm{~g} \text { of }\end{array}$ & $\begin{array}{r}1.014 \\
0.266 \\
.301 \\
.357 \\
.494\end{array}$ & $\begin{array}{r}1.00 \\
0.26 \\
.30 \\
.35 \\
.49\end{array}$ & $\begin{array}{l}6.4 \\
5.3 \\
5.9 \\
5.6 \\
7.2\end{array}$ & $\begin{array}{r}0.853 \\
.187 \\
.374 \\
.423 \\
.492\end{array}$ & $\begin{array}{r}1.00 \\
0.22 \\
.44 \\
.50 \\
.58\end{array}$ & $\begin{array}{l}6.5 \\
5.2 \\
5.6 \\
5.5 \\
7.0\end{array}$ & $\begin{array}{r}0.516 \\
.307 \\
.376 \\
.398 \\
.424\end{array}$ & $\begin{array}{r}1.00 \\
0.59 \\
.73 \\
.77 \\
.82\end{array}$ & $\begin{array}{l}\text { 6. } 6 \\
5.2 \\
5.6 \\
5.2 \\
7.1\end{array}$ \\
\hline & $\begin{array}{l}\text { Solid } \mathrm{CaCO}_{3} \text {. } \\
1 \mathrm{ml} \text { of } 25 \% \mathrm{NaClO}_{2}, 1 \mathrm{ml} \text { of saturated } \\
\mathrm{NaHCO} \mathrm{CO}_{3} \text { solution. }\end{array}$ & 1.325 & 1.31 & 8.7 & .822 & .96 & 8.0 & .401 & .78 & 6. 8 \\
\hline & $\begin{array}{l}0.3 \mathrm{ml} \text { of } 12.5 \% \mathrm{Ca}\left(\mathrm{ClO}_{2}\right)_{2}, 1.5 \mathrm{ml} \text { of } 4.9 \% \\
\mathrm{Ca}(\mathrm{ClO})_{2} \text {. }\end{array}$ & 0.736 & 0.73 & 6.3 & .787 & .92 & 6.0 & .491 & .95 & 6. 0 \\
\hline & $\begin{array}{l}0.3 \mathrm{ml} \mathrm{of} 25 \% \mathrm{NaClO}_{2}+2.25 \mathrm{ml} \text { of } 4.9 \% \\
\mathrm{Ca}(\mathrm{ClO})_{2} \text {. }\end{array}$ & .840 & .83 & 6.4 & .866 & 1.02 & 6.2 & .506 & .98 & 5.9 \\
\hline $9 .$. & $\begin{array}{l}0.15 \mathrm{ml} \text { of } 25 \% \mathrm{NaClO}_{2}+2.25 \mathrm{ml} \text { of } 4.9 \% \\
\mathrm{Ca}(\mathrm{ClO})_{2} .\end{array}$ & .834 & .82 & 6.4 & .828 & 0.97 & 6.2 & .513 & .99 & 5.1 \\
\hline
\end{tabular}

- The "specific absorptive index," - $\log t$, is the absorptive index of a solution of the sugar reduced to unit conditions regarding thickness and concentration. It is calculated from the equation $-\log t=-\log T / b c$, in which $b$ is the thickness in centimeters of the absorbing solution, $c$ is the concentration of the sugar in grams per milliliter, and $T$ is the transmission of the standard plate as given by calibration at $560 \mathrm{~m} \mu$.

b The ratio of the "specific absorptive index" of the sugar mixture to the "specific absorptive index" of the sugar treated in like manner but without the addition of either chlorites or hypochlorites.

- The acidity of a solution containing $1 \mathrm{~g}$ of the sugar mixture dissolved in $3 \mathrm{~g}$ of water.

The addition of chlorite and the ensuing bleaching action usually leads to an increase in the acidity of the sugar mixture. This objectionable feature may be overcome by the addition of a base or buffer to the raw-sugar mixture. The buffer neutralizes any acid formed while the sugar is in storage, and thus lowers the loss of sugar by hydrolysis. The bleaching action is retarded by the addition of the base or buffer; but this retardation is immaterial, because ordinarily the sugar is kept in storage for a long time. Furthermore, the slower the reaction the longer the chlorite remains in contact with the sugar and protects it from bacterial action. In experiment 6 , table 1 , in which sodium bicarbonate was added, in addition to sodium chlorite, the color increased at first and then decreased slowly; after 55 days the specific absorptive index was 0.78 of that of the sugar in the control 
experiment. Treatment of the sugar with a mixture of chlorite and hypochlorite (experiments 7,8 , and 9) caused a rapid decrease in color, but the bleaching effect was not so permanent as that obtained by the use of chlorites alone. After standing for 7 days, there was little difference in the appearance of the samples treated with the chlorite-hypochlorite mixtures and the appearance of the control sample.

The change in color given in table 1 is not an adequate measure of the value of the treatment. From a practical viewpoint the value of the treatment depends in part on the behavior of the sugar in the subsequent purification steps. Although the colored impurities which remain in the solutions after treatment with chlorites are easily removed by filtration over bone char, the discussion of this phase of the subject must await further investigation. In the technological application of the process, the raw sugar might be sprayed in the centrifugal with a solution containing the chlorite and buffer. This is a simple procedure, and does not require equipment or steps other than those ordinarily used in the production of sugar.

\section{EXPERIMENTS WITH SUGAR SOLUTIONS}

Although the method for treating raw sugar outlined in the preceding paragraph is very simple and convenient, in some cases it may be desirable to bleach sugar solutions or to conduct the bleaching operation at another stage in the manufacturing process. At most points in the process a very slow reaction would be objectionable, and hence a series of measurements was made with the purpose of ascertaining whether or not the rate of bleaching could be increased by increasing the acidity or by adding a hypochlorite in a manner analogous to the procedure already used for bleaching cellulose fibers (see footnote 1 ).

TABLE 2.-Effect of acidity on the bleaching action of chlorites in raw-sugar solutiong

\begin{tabular}{|c|c|c|c|c|c|c|c|c|c|c|c|c|}
\hline \multirow{2}{*}{ Time } & \multicolumn{3}{|c|}{$\begin{array}{l}100 \mathrm{~g} \text { of sugar } \\
100 \mathrm{~g} \text { of water } \\
1 \mathrm{~g} \mathrm{of} \mathrm{NaClO}_{2}\end{array}$} & \multicolumn{3}{|c|}{$\begin{array}{l}100 \mathrm{~g} \text { of sugar } \\
100 \mathrm{~g} \text { of water } \\
1 \mathrm{~g} \text { of } \mathrm{NaClO}_{2} \\
1.6 \mathrm{ml} \text { of } 1 \mathrm{M}_{3} \mathrm{PO}_{4}\end{array}$} & \multicolumn{3}{|c|}{$\begin{array}{l}100 \mathrm{~g} \text { of sugar } \\
100 \mathrm{~g} \text { of water } \\
1 \mathrm{~g} \mathrm{of} \mathrm{NaClO}_{3} \\
0.4 \mathrm{ml} \text { of } 1 \mathrm{M}_{3} \mathrm{PO}_{4}\end{array}$} & \multicolumn{3}{|c|}{$\begin{array}{l}100 \mathrm{~g} \text { of sugar } \\
100 \mathrm{~g} \text { of water } \\
1 \mathrm{~g} \text { of } \mathrm{NaClO} 2 \\
0.1 \mathrm{~g} \text { of } \mathrm{NaHCO}_{2}\end{array}$} \\
\hline & $\begin{array}{l}\text { Acid- } \\
\text { ity, } \\
\text { pHi }\end{array}$ & $\begin{array}{c}\text { Specific } \\
\text { absorp- } \\
\text { tive } \\
\text { index } \\
-\log t\end{array}$ & $\begin{array}{l}\text { Rela- } \\
\text { tive } \\
\text { absorp- } \\
\text { tive } \\
\text { index a }\end{array}$ & $\begin{array}{l}\text { Acid- } \\
\text { ity, } \\
\text { pH }\end{array}$ & $\begin{array}{c}\text { Specific } \\
\text { absorp- } \\
\text { tive } \\
\text { index } \\
-\log t\end{array}$ & $\begin{array}{l}\text { Rela- } \\
\text { tive } \\
\text { absorp- } \\
\text { tive } \\
\text { index a }\end{array}$ & $\begin{array}{l}\text { Acid- } \\
\text { ity, } \\
\text { pḦ }\end{array}$ & $\begin{array}{c}\text { Specific } \\
\text { absorp- } \\
\text { tive } \\
\text { index } \\
-\log t\end{array}$ & $\begin{array}{l}\text { Rela- } \\
\text { tive } \\
\text { absorp- } \\
\text { tive } \\
\text { index }\end{array}$ & $\begin{array}{l}\text { Acid- } \\
\text { ity, } \\
\text { pH }\end{array}$ & $\begin{array}{c}\text { Specific } \\
\text { absorp- } \\
\text { tive } \\
\text { index, } \\
-\log t\end{array}$ & $\begin{array}{l}\text { Rela- } \\
\text { tive } \\
\text { absorp- } \\
\text { tive } \\
\text { index }\end{array}$ \\
\hline $\begin{array}{l}\text { Hours } \\
0.5 \\
2 \\
6 \\
24\end{array}$ & $\begin{array}{l}6.1 \\
6.1 \\
6.1 \\
6.1\end{array}$ & $\begin{array}{r}1.050 \\
0.855 \\
.753 \\
.608\end{array}$ & $\begin{array}{r}1.14 \\
0.93 \\
.82 \\
.66\end{array}$ & $\begin{array}{l}\text { 4. } 2 \\
\text { 4. } 2 \\
\text { 4. } 2 \\
\text { 4. } 2\end{array}$ & $\begin{array}{r}0.410 \\
.115 \\
\end{array}$ & \begin{tabular}{r}
0.45 \\
.13 \\
\hdashline .13 \\
\end{tabular} & $\begin{array}{l}5.1 \\
5.1 \\
5.1 \\
4.9\end{array}$ & $\begin{array}{r}0.691 \\
.587 \\
.450 \\
.193\end{array}$ & $\begin{array}{l}0.75 \\
.64 \\
.49 \\
.21\end{array}$ & $\begin{array}{l}8.2 \\
8.2 \\
8.2 \\
8.1\end{array}$ & $\begin{array}{l}\text { 1. } 231 \\
1.262 \\
1.262 \\
1.262\end{array}$ & $\begin{array}{l}\text { 1. } 34 \\
1.37 \\
1.37 \\
1.37\end{array}$ \\
\hline
\end{tabular}

- The ratio of the "specific absorptive index" of the sugar mixture to that of the untreated raw sugar.

The results given in table 2 show that the bleaching of raw-sugar solutions with chlorites is more rapid in strongly acid solution than in weakly acid solution and that there is no appreciable bleaching in alkaline solution, as, for example, in the experiment in which sodium bicarbonate was added. The increase in the intensity of color noted in the sodium bicarbonate solution is largely caused by the alkaline reaction and disappears when the solution is made acid. 
Upon the addition of sodium chlorite to a solution containing the raw sugar, the yellow-brown color increases slightly at first, but decreases on standing so that ultimately a decided bleaching action is obtained. The cause of the initial increase in color is not known, but a similar increase in color is found when raw sugar is treated with calcium hypochlorite (table 3 ).

TABLE 3.-Treatment of raw-sugar solutions with chlorites in conjunction with hypochlorites at approximately $26^{\circ} \mathrm{C}$

\begin{tabular}{|c|c|c|c|c|c|c|c|c|}
\hline \multicolumn{3}{|c|}{$\begin{array}{l}100 \mathrm{~g} \text { of sugar dissolved in } 100 \mathrm{~g} \text { of } \\
\text { water plus the reagents indicated } \\
\text { below }\end{array}$} & \multicolumn{2}{|c|}{$\begin{array}{l}0.5 \text { hour after addition } \\
\text { of reagents }\end{array}$} & \multicolumn{2}{|c|}{$\begin{array}{c}20 \text { hours after addition } \\
\text { of reagents }\end{array}$} & \multicolumn{2}{|c|}{$\begin{array}{l}100 \text { hours after } \\
\text { addition of reagents }\end{array}$} \\
\hline $\mathrm{NaClO}_{3}$ & $\mathrm{Ca}(\mathrm{ClO})_{2}$ & $1 \mathrm{MH}_{3} \mathrm{PO}_{4}$ & $\mathrm{pH}$ & $\begin{array}{l}\text { Relative } \\
\text { absorptive } \\
\text { index } \&\end{array}$ & $\mathrm{pH}$ & $\begin{array}{l}\text { Relative } \\
\text { absorptive } \\
\text { index } *\end{array}$ & $\mathrm{pH}$ & $\begin{array}{l}\text { Relative } \\
\text { absorptive } \\
\text { index * }\end{array}$ \\
\hline $\begin{array}{l}g_{0} \\
0.5 \\
1.0\end{array}$ & $g$ & $m l$ & $\begin{array}{l}6.2 \\
6.2 \\
6.1\end{array}$ & $\begin{array}{l}1.00 \\
1.12 \\
1.14\end{array}$ & & $\begin{array}{l}1.00 \\
.83 \\
0.65\end{array}$ & 5.7 & $\begin{array}{r}1.00 \\
0.40 \\
-\end{array}$ \\
\hline $\begin{array}{r}0.1 \\
.2 \\
.5\end{array}$ & (n) & $\begin{array}{r}0.8 \\
.8 \\
.8\end{array}$ & $\begin{array}{l}4.8 \\
4.8 \\
4.8\end{array}$ & $\begin{array}{l}0.92 \\
.84 \\
.79\end{array}$ & $\begin{array}{l}4.8 \\
4.8 \\
4.8\end{array}$ & $\begin{array}{l}.54 \\
.52 \\
.33\end{array}$ & $\begin{array}{l}4.9 \\
4.8 \\
4.1\end{array}$ & $\begin{array}{l}.41 \\
.25 \\
.03\end{array}$ \\
\hline 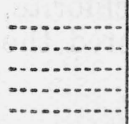 & $\begin{array}{l}0.2 \\
.6 \\
.1 \\
.2 \\
.6\end{array}$ & $\begin{array}{l}.8 \\
.8 \\
.8\end{array}$ & $\begin{array}{l}6.9 \\
7.1 \\
5.1 \\
5.2 \\
5.7\end{array}$ & $\begin{array}{r}1.31 \\
0.50 \\
.92 \\
.81 \\
.21\end{array}$ & $\begin{array}{r}6.6 \\
5.0 \\
5.1 \\
5.2\end{array}$ & $\begin{array}{l}.59 \\
.53 \\
.93 \\
.93 \\
.47\end{array}$ & $\begin{array}{l}6.3 \\
6.6 \\
4.9 \\
5.0 \\
5.0\end{array}$ & $\begin{array}{r}.62 \\
.60 \\
.95 \\
1.00 \\
0.52\end{array}$ \\
\hline $\begin{array}{l}.1 \\
.1 \\
.1\end{array}$ & .12 & & $\begin{array}{l}6.8 \\
7.0 \\
7.2\end{array}$ & $\begin{array}{l}\text { 1. } 22 \\
\text { 1. } 25 \\
0.83\end{array}$ & $\begin{array}{l}6.4 \\
6.4 \\
6.3\end{array}$ & $\begin{array}{l}1.10 \\
1.12 \\
0.59\end{array}$ & $\begin{array}{l}6.2 \\
6.2 \\
6.3\end{array}$ & $\begin{array}{r}1.00 \\
0.89 \\
.48\end{array}$ \\
\hline $\begin{array}{l}.2 \\
.2 \\
.2\end{array}$ & $\begin{array}{l}.2 \\
.4 \\
.6\end{array}$ & & $\begin{array}{l}7.2 \\
7.2 \\
7.3\end{array}$ & $\begin{array}{r}1.25 \\
0.71 \\
.15\end{array}$ & $\begin{array}{l}6.5 \\
6.3 \\
6.1\end{array}$ & $\begin{array}{r}1.08 \\
0.46 \\
.10\end{array}$ & $\begin{array}{l}6.2 \\
5.9 \\
5.5\end{array}$ & $\begin{array}{l}.69 \\
.25 \\
.05\end{array}$ \\
\hline $\begin{array}{l}.5 \\
.5 \\
.5\end{array}$ & $\begin{array}{l}.2 \\
.4 \\
.6\end{array}$ & (1) & $\begin{array}{l}7.0 \\
7.1 \\
6.5\end{array}$ & $\begin{array}{r}1.06 \\
0.57 \\
.22\end{array}$ & - & $\begin{array}{l}.61 \\
.15 \\
.12\end{array}$ & $\begin{array}{l}5.8 \\
5.0 \\
4.7\end{array}$ & $\begin{array}{l}.24 \\
.03 \\
.03\end{array}$ \\
\hline $\begin{array}{l}.05 \\
.05 \\
.1\end{array}$ & $\begin{array}{l}.3 \\
.4 \\
.1\end{array}$ & $\begin{array}{l}.8 \\
.8 \\
.8\end{array}$ & $\begin{array}{l}5.5 \\
5.5 \\
5.0\end{array}$ & $\begin{array}{c}.33 \\
.85\end{array}$ & $\begin{array}{l}5.0 \\
5.0 \\
4.9\end{array}$ & $\begin{array}{l}.57 \\
.46 \\
.65\end{array}$ & $\begin{array}{l}5.0 \\
4.9 \\
4.9\end{array}$ & $\begin{array}{l}.60 \\
.64 \\
.69\end{array}$ \\
\hline $\begin{array}{l}.1 \\
.1 \\
.2\end{array}$ & $\begin{array}{l}.2 \\
.4 \\
.2\end{array}$ & $\begin{array}{l}.8 \\
.8 \\
.8\end{array}$ & $\begin{array}{l}5.3 \\
5.4 \\
5.0\end{array}$ & .71 & $\begin{array}{l}5.1 \\
5.0\end{array}$ & $\begin{array}{l}.46 \\
.25 \\
.29\end{array}$ & $\begin{array}{l}5.0 \\
5.0 \\
4.7\end{array}$ & $\begin{array}{l}.44 \\
.42 \\
.13\end{array}$ \\
\hline $\begin{array}{l}.2 \\
.2 \\
.5 \\
.5\end{array}$ & $\begin{array}{l}.3 \\
.4 \\
.2 \\
.4\end{array}$ & $\begin{array}{l}.8 \\
.8 \\
.8 \\
.8\end{array}$ & $\begin{array}{l}5.0 \\
5.4 \\
5.4 \\
5.6\end{array}$ & .66 & $\begin{array}{l}4.9 \\
0.9\end{array}$ & $\begin{array}{l}.16 \\
.08 \\
.14 \\
.07\end{array}$ & $\begin{array}{l}4.7 \\
4.9 \\
4.0 \\
3.9\end{array}$ & $\begin{array}{l}.06 \\
.20 \\
.03 \\
.06\end{array}$ \\
\hline
\end{tabular}

a The ratio of the "specific absorptive index" of the sample to that of the untreated raw sugar. The absorptive index $(-\log t)$ of the untreatcd raw sugar was 0.919 at $560 \mathrm{mu}$.

Table 3 gives the results obtained from a series of experiments in which different quantities of sodium chlorite, calcium hypochlorite, and phosphoric acid were added to raw-sugar solutions. The specific absorptive index of the solution treated with $0.5 \mathrm{~g}$ of sodium chlorite after 100 hours was 0.40 of that of the untreated sugar solution, whereas the specific absorptive index of a similar solution containing, in addition to the chlorite, $0.8 \mathrm{ml}$ of $1 M$ phosphoric acid, was only 0.03 of that of the untreated sugar solution. The use of both sodium chlorite and calcium hypochlorite gives a more rapid bleaching effect in a more nearly neutral medium. Thus the specific absorptive index of the sample treated with $0.2 \mathrm{~g}$ of sodium chlorite and $0.6 \mathrm{~g}$ of calcium hypochlorite decreased in 0.5 hour to 0.15 of the original value, while 
the acidity was pH 7.3. Although the bleaching effect of hypochlorites appears to be more rapid than the bleaching effect of chlorites, it appears to be less permanent. It is known that chlorites in aqueous solution react with hypochlorites to give chlorine dioxide. This substance is an excellent bleaching agent and may account for the rapid bleaching of raw sugars by a mixture of chlorite and hypochlorite. The bleaching action of chlorites may also be due in large part to the formation of chlorine dioxide, and the rate of bleaching may be determined by its rate of formation.

The results given in table 4 show the bactericidal and fungicidal effect of the addition of chlorites to a 50-Brix solution of raw sugar. The solutions were kept at room temperature in glass bottles under conditions favorable for the growth of bacteria and molds. An examination of the solutions after standing for 5 months revealed mycelia in all of the samples not treated with chlorites, while those treated with chlorites, with the exception of numbers 10,11 , and 12 , failed to show visible growths. Concentrations of calcium hypochlorite six times as high as the concentrations found to be effective for sodium chlorite did not prevent the appearance of mold or bacterial growths. The lower bactericidal action of chlorites in the presence of hypochlorites and phosphoric acid, illustrated by the results of solutions 10,11, and 12 , may be explained by the interaction of the chlorite, hypochlorite, and acid, which removed the chlorite from solution and lowered the bactericidal effect.

TABLE 4.-Inhibition of the formation of mold or bacterial growths by the addition of chlorites and hypochlorites to solutions of raw sugar

\begin{tabular}{|c|c|c|c|c|}
\hline \multirow{2}{*}{ Solution number } & \multicolumn{3}{|c|}{$\begin{array}{c}\text { Reagents added to each } 200 \mathrm{~g} \text { of } 50 \text {-Brix } \\
\text { sugar solution }\end{array}$} & \multirow{2}{*}{$\begin{array}{l}\text { Condition of solution after } \\
\text { standing for } 5 \text { months in } \\
\text { glass-stoppered bottles at } \\
\text { room temperature }\end{array}$} \\
\hline & $\mathrm{NaClO}_{2}$ & $\mathrm{Ca}(\mathrm{ClO})_{2}$ & $1 M \mathrm{H}_{3} \mathrm{PO}_{4}$ & \\
\hline $\begin{array}{l}1 \\
2 \\
3 \\
4\end{array}$ & $\begin{array}{r}0.1 \\
.1 \\
.2 \\
.5 \\
.1\end{array}$ & $\begin{array}{c}g \\
\\
\end{array}$ & $\begin{array}{r}m l \\
0.8 \\
0 \\
0\end{array}$ & $\begin{array}{l}\text { No mycelium. } \\
\text { Do. } \\
\text { Do. } \\
\text { Do. } \\
\text { Do. }\end{array}$ \\
\hline $\begin{array}{l}6 \\
6 \\
8 \\
8\end{array}$ & $\begin{array}{l}.1 \\
.1 \\
.2 \\
.2 \\
.1\end{array}$ & $\begin{array}{l}.2 \\
.4 \\
.2 \\
.4 \\
.4\end{array}$ & 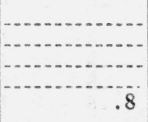 & $\begin{array}{l}\text { Do. } \\
\text { Do. } \\
\text { Do. } \\
\text { Do. } \\
\text { Mycelium present. }\end{array}$ \\
\hline 112 & 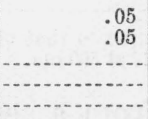 & $\begin{array}{l}.4 \\
.3 \\
.6 \\
.2 \\
.1\end{array}$ & $\begin{array}{l}.8 \\
.8 \\
.8 \\
.8 \\
.8\end{array}$ & $\begin{array}{l}\text { Do. } \\
\text { Do. } \\
\text { Do. } \\
\text { Do. } \\
\text { Do. }\end{array}$ \\
\hline 16 & $\ldots$ & .2 & - n & $\begin{array}{l}\text { Do. } \\
\text { Do. }\end{array}$ \\
\hline
\end{tabular}

Although the experiments described in this paper show the possible useifulness of chlorites for treating raw sugars, the commercial application of chlorite in the refining of sugar might involve some complications which it may not be amiss to consider briefly. The most objectionable feature of the use of chlorites is the danger of fire or explosion. In this connection, the effect of chlorites on the spontaneous combustion of sugar and on the inflammability of sugar dust are 
problems of importance. Furthermore, chlorites and chlorine dioxide are toxic compounds and might affect the health of the workers adversely. Hence the physiological effects of chlorites and chlorine dioxide should be investigated in order to ascertain safe working conditions. In the final analsyis the use of chlorites by the sugar industry will depend on whether or not their use can reduce the cost of producing refined sugar. This can be ascertained only by extensive investigation, closely coordinated with the sugar industry.

Washington, October 10, 1941. 